\title{
Effect of the Skilled Worker Certification on the Sustainable Infrastructure Development
}

\author{
Nurin Pramadini \\ Construction Service Agency Region IV Unit, Ministry of Public Works and Public Housing, Surabaya, INDONESIA \\ pramadini@gmail.com \\ Inggar Septhia Irawaty \\ Magister of Infrastructure and Material Technology, Gadjah Mada University, Yogyakarta, INDONESIA \\ inggar_septhia@ugm.ac.id \\ Ashar Saputra \\ Magister of Infrastructure and Material Technology, Gadjah Mada University, Yogyakarta, INDONESIA \\ saputra@ugm.ac.id
}

\begin{abstract}
Infrastructure plays an important role in the process of achieving development goals, and human resources are an important factor that determines the success of the development program. This research was conducted in the working area of Construction Training Center II Region Surabaya. Data were collected using questionnaires or questions list, distributed to respondents, namely providers and users of the skilled labor. The respondents consisted of 60 people, 30 of each was certified and uncertified skilled workers. Data was processed using SPSS. The results show that the number of certified skilled workers who know the characteristics of sustainable infrastructure is higher than that of the uncertified skilled workers. An average of $95.4 \%$ of certified skilled workers know the characteristics, while only $91.1 \%$ for uncertified skilled workers. Certified workers who apply sustainable infrastructure characteristics are about $75.9 \%$ and, while only $62.8 \%$ for non-certified workers. The analysis shows that there is significant influence of knowledge of the characteristics of sustainable infrastructure on the project implementation.
\end{abstract}

Keywords: Certification, workers, infrastructure, sustainable

\section{INTRODUCTION}

The success of development is determined by the availability of reliable infrastructure. Awareness to implement sustainable development should always be put forward, where the environment is regarded as the greatest asset that must be preserved in every step of the implementation of infrastructure development. In infrastructure development, there is a key factor that play very important role, namely human resource. To achieve sustainable development, the development of the construction workforce needs to be a common focus, especially on developing the competence of the workforce on sustainability characteristics and its implementation in the field. The enhancement of construction workers competency could be carried out in various ways, one of it is by training. Competencybased Training is a work training that emphasizes on the working skill mastery, which consists of knowledge, skill, and working manner, as according to the requirement and standard of the working place (Ministry of Public Works and Public Housing, 2014a; Ministry of Public Works and Public Housing, 2014b).
Several studies have examined this issue, among other is discussing the effect of Green Construction implementation on development on project quality performance (Usman \& Furqan, 2010); and also discussing an integrated knowledge management framework for managing sustainability knowledge in the Australian infrastructure sector (Yuan, 2011). In addition, there were other studies discussing the training of construction workers for sustainable environments (Kakkar \& Anju, 2014). The difference of the present study with previous research is that this study examines how sustainable infrastructure development in Indonesia is influenced by skilled workers - whether certified or not - knowledge and application.

The research was expected to be able to improve knowledge on skilled workers; to be a reference in conducting research on the area of construction workers development, particularly towards the sustainable infrastructure development. 


\section{THE SUSTAINABLE INFRASTRUCTURES DEVELOPMET}

The World Commission on Environment and Development defines sustainable development as "meets the needs of the present without compromising the ability of future generations to meet their own needs" (World Commission on Environment and Development, 1987). In the Triple Bottom Line, as seen in Figure 1, Sustainability consists of social sustainability, economic sustainability, and environmental sustainability (Rasekh \& Haleh, 2013).

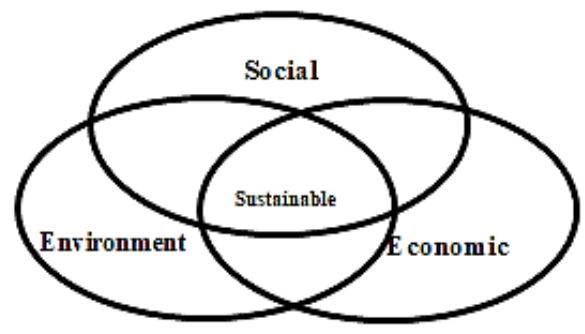

Figure 1. Triple Bottom Line Diagram (Rodriguez, et al., 2002)

Kakkar \& Anju (2014) state that sustainable development can only be achieved when the workers working on the building understand the concept of sustainable materials and how to reduce waste materials. Awareness of the meaning of sustainability should start from the training process of the workers who will contribute to the development process.

Indonesia is in the process of becoming, as well as promoting, the adoption of sustainable construction. This means developing a construction industry that is environmentally friendly, nondestructive to ecological, and energy efficient. The development should put concern for a better quality of life but remain more competitive and more profitable. This means prioritizing customer satisfaction and convenience, and able to protect the environment and minimize the use of energy resources (Goeritno \& Bambang, 2011). The goal of sustainable infrastructure management is to achieve sustainable infrastructure conditions, either in the process of programming, technical planning, constructing, utilization, and even when dismantled - while taking into account the achievement of the economic, social and environmental aspects, in the present and future.

There are standards and requirements that need to be fulfilled when carrying out construction process. In this standards and requirements, safety is the most highly noted aspect, but not so much attention is paid toward aspects of sustainability concept. Therefore, there is a Rating System to measure the sustainability of a project. Rating System is a tool used to guide in measuring a sustainable construction. It has several characteristics to achieve sustainable development through value transition programs (Basso \& Louise, 2012).

\section{RESEARCH METHOD}

\subsection{Location}

This research was conducted in the work area of the Construction Training Agency Region II Surabaya Unit (Balai Pelatihan Konstruksi Wilayah II Surabaya).

\subsection{Respondent}

Respondents in this study were skilled construction workers, both with and without certification; and were located in Construction Training Unit Area II Surabaya, which includes Central Java, Special Region of Yogyakarta, East Java, Bali, West Nusa Tenggara and East Nusa Tenggara. Sixty (60) questionnaires were obtained, consisted of 30 each of certified and uncertified skilled workers, respectively. The general review of the respondents' background is presented in Table 1 .

Table 1. Respondents data

\begin{tabular}{|c|c|c|c|c|}
\hline \multirow[t]{2}{*}{ Note } & \multicolumn{4}{|c|}{ Sample total } \\
\hline & \multicolumn{2}{|c|}{ Certified } & \multicolumn{2}{|c|}{ Non-certified } \\
\hline \multicolumn{5}{|l|}{ Respondent Role } \\
\hline Project Owner & 12 & $40 \%$ & 10 & $36.7 \%$ \\
\hline - Consultant & 9 & $30 \%$ & 9 & $30 \%$ \\
\hline Contractor & 9 & $30 \%$ & 11 & $33.3 \%$ \\
\hline \multicolumn{5}{|l|}{ Work experience } \\
\hline$-\quad 0-5$ years & 2 & $6.7 \%$ & 16 & $53.3 \%$ \\
\hline $5-10$ years & 11 & $36.7 \%$ & 9 & $30 \%$ \\
\hline $10-15$ years & 6 & $20 \%$ & 2 & $6.7 \%$ \\
\hline $15-20$ years & 5 & $16.7 \%$ & 0 & $0 \%$ \\
\hline $20-25$ years & 6 & $20 \%$ & 3 & $10 \%$ \\
\hline \multicolumn{5}{|l|}{ Education Degree } \\
\hline Undergraduate & 19 & $63.3 \%$ & 26 & $86.7 \%$ \\
\hline Graduate & 11 & $36.7 \%$ & 4 & $13.3 \%$ \\
\hline
\end{tabular}

\subsection{Data Collection}

In this research, the data was collected through questionnaire or question list. The questionnaire could be defined as data collection technique in which a list of question is being sent to the respondent in order to be filled.

\subsection{Questionnaire}

The research questionnaire included variables adapted from the explanation in the Regulation of Ministry of Public Works and Housing No.5/2015 (Ministry of Public Works and Housing, 2015) which consisted of work stages variable, whereas the measured indicators are the summary of stages on the sustainable 
construction step. Whilst the sustainable infrastructure characteristic consisted of variable of life quality, leadership, resource allocation, nature, and climate; these were adapted from sub-variable of preevaluation list of the Envision rating system. There were 65 variables on this research, and have five measurement alternatives of the Likert scale: 1 (Strongly Disagree), 2 (Disagree), 3 (Neither agrees nor disagrees), 4 (Agree), 5 (Strongly Agree), and one choice of N/A (Not Applicable).
The adaptation of questionnaire variables was carried out by considering that both regulations have been planned and discussed by experts so that it already contains the requirements of the Sustainable Infrastructure. Therefore, information or implementation of work that meet the criteria of Sustainable Infrastructure can be discovered from filling the aforementioned questionnaire. The research variables are as shown in Table 2.

Table 2. Questionnaire variables

\begin{tabular}{|c|c|c|}
\hline \multirow{2}{*}{$\begin{array}{l}\text { Variable } \\
\text { Activity Stage }\end{array}$} & \multicolumn{2}{|c|}{ Indicator } \\
\hline & $\mathrm{X}_{1.1}$ & Identification of interested parties \\
\hline & $\mathrm{X}_{1.2}$ & Choosing professional service provider according to its appropriate field \\
\hline & $\mathrm{X}_{1.3}$ & Discussing target, scope, and aim, with all involved parties \\
\hline & $\mathrm{X}_{1.4}$ & Setting framework criteria based on related technical requirements \\
\hline & $\mathrm{X}_{1.5}$ & Conducting integrated technical planning process with all involved parties \\
\hline & $\mathrm{X}_{1.6}$ & Reviewing the result of technical planning \\
\hline & $\mathrm{X}_{1.7}$ & $\begin{array}{l}\text { Applying the green construction approach on the construction work implementation on } \\
\text { the field }\end{array}$ \\
\hline & $\mathrm{X}_{1.8}$ & Conducting sustainable infrastructure construction implementation \\
\hline & $\mathrm{X}_{1.9}$ & $\begin{array}{l}\text { Ensuring that result from each construction implementation step could be utilized } \\
\text { effectively }\end{array}$ \\
\hline & $\mathrm{X}_{1.10}$ & Preparing final report \\
\hline \multirow[t]{12}{*}{ Life quality } & $\mathrm{X}_{2.1}$ & Increasing communities life quality \\
\hline & $\mathrm{X}_{2.2}$ & Generating sustainable growth and development \\
\hline & $\mathrm{X}_{2.3}$ & Developing local skill and ability \\
\hline & $\mathrm{X}_{2.4}$ & Increasing public health and security \\
\hline & $\mathrm{X}_{2.5}$ & Minimalizing noise and vibration \\
\hline & $\mathrm{X}_{2.6}$ & Minimalizing light pollution \\
\hline & $\mathrm{X}_{2.7}$ & Increasing communication access and mobility \\
\hline & $\mathrm{X}_{2.8}$ & Encourage alternative transportation mode \\
\hline & $\mathrm{X}_{2.9}$ & Increasing access to field, road, and security \\
\hline & $\mathrm{X}_{2.10}$ & Preserving local culture and history \\
\hline & $\mathrm{X}_{2.11}$ & Guarding local/traditional views and characters \\
\hline & $\mathrm{X}_{2.12}$ & Increasing public space \\
\hline \multirow[t]{9}{*}{ Leadership } & $\mathrm{X}_{3.1}$ & Providing commitment and effective leadership \\
\hline & $\mathrm{X}_{3.2}$ & Composing sustainable management system \\
\hline & $\mathrm{X}_{3.3}$ & Develop teamwork \\
\hline & $\mathrm{X}_{3.4}$ & Assign engagement from another party \\
\hline & $\mathrm{X}_{3.5}$ & Pursue opportunity from secondary result alloy \\
\hline & $\mathrm{X}_{3.6}$ & Improve infrastructure integration \\
\hline & $\mathrm{X}_{3.7}$ & Planning long-term monitoring and maintenance \\
\hline & $\mathrm{X}_{3.8}$ & Locate conflicting policies and regulations \\
\hline & $\mathrm{X}_{3.9}$ & Increasing service time \\
\hline \multirow[t]{9}{*}{ Resource allocation } & $\mathrm{X}_{4.1}$ & Reduce energy expenditure \\
\hline & $\mathrm{X}_{4.2}$ & Support the implementation of sustainable procurement \\
\hline & $\mathrm{X}_{4.3}$ & Using recycled materials \\
\hline & $\mathrm{X}_{4.4}$ & Using local materials \\
\hline & $\mathrm{X}_{4.5}$ & Redirecting trash from landfills \\
\hline & $\mathrm{X}_{4.6}$ & Reducing material transport to out of area \\
\hline & $\mathrm{X}_{4.7}$ & Providing re-fixing and recycling \\
\hline & $\mathrm{X}_{4.8}$ & Reducing energy consumption \\
\hline & $\mathrm{X}_{4.9}$ & Using renewable energy source \\
\hline \multirow[t]{4}{*}{ Resource allocation } & $\mathrm{X}_{4.10}$ & Prepare and supervise the energy system \\
\hline & $\mathrm{X}_{4.11}$ & Protect the availability of clean water \\
\hline & $\mathrm{X}_{4.12}$ & Reduce drinking water/clean water consumption \\
\hline & $\mathrm{X}_{4.13}$ & Supervise water cycle \\
\hline
\end{tabular}


Table 2. Questionnaire variable (continued)

\begin{tabular}{|c|c|c|}
\hline Variable & Indic: & \\
\hline Nature & $\mathrm{X}_{5.1}$ & Maintain primary habitat \\
\hline & $\mathrm{X}_{5.2}$ & Protect wetlands and surface water \\
\hline & $\mathrm{X}_{5.3}$ & Maintain the main agricultural land \\
\hline & $\mathrm{X}_{5.4}$ & Avoid geological destruction \\
\hline & $\mathrm{X}_{5.5}$ & Maintain the function of flood areas \\
\hline & $\mathrm{X}_{5.6}$ & Avoiding unsuitable construction on steep slopes \\
\hline & $\mathrm{X}_{5.7}$ & Maintaining green area \\
\hline & $\mathrm{X}_{5.8}$ & Arrange water flow \\
\hline & $\mathrm{X}_{5.9}$ & Reduce effect from fertilizers and pesticides \\
\hline & $\mathrm{X}_{5.10}$ & Avoid contamination of ground water and surface water \\
\hline & $\mathrm{X}_{5.11}$ & Maintaining species biodiversity \\
\hline & $\mathrm{X}_{5.12}$ & Controlling destructive species \\
\hline & $\mathrm{X}_{5.13}$ & Recovering damaged soil \\
\hline & $\mathrm{X}_{5.14}$ & Maintaining the function of wetlands and surface water \\
\hline Climate & $\mathrm{X}_{6.1}$ & Reduce greenhouse gas emissions \\
\hline & $\mathrm{X}_{6.2}$ & Reduce air pollution \\
\hline & $\mathrm{X}_{6.3}$ & Measure climate threat \\
\hline & $\mathrm{X}_{6.4}$ & Avoid long-term risks and vulnerabilities due to climate \\
\hline & $\mathrm{X}_{6.5}$ & Prepare for long-term adaptability \\
\hline & $\mathrm{X}_{6.6}$ & Prepare short-term hazards \\
\hline & $\mathrm{X}_{6.7}$ & Managing the effects of global warming \\
\hline
\end{tabular}

\subsection{Research Flow Chart}

The research was conducted by formulating, distributing questionnaires to respondents and processing respondent's data in order to formulate the answer for research questions as expressed in variable. After the questionnaire was prepared, it was delivered to the respondents to collect the primary data. When reaching a sufficient number, then the analysis and discussion were carried out to formulate the answers of the research objectives. The detail of research stages can be seen in flowchart as depicted Figure 2.

\subsection{Data Analysis}

Data obtained from survey results were analyzed using SPSS software focusing on the influence of respondents' backgrounds, namely education, training certificates, or work type, and also determining the relationship between respondents' knowledge on characteristics of Sustainable Infrastructure in the implementation of the projects they have experienced.

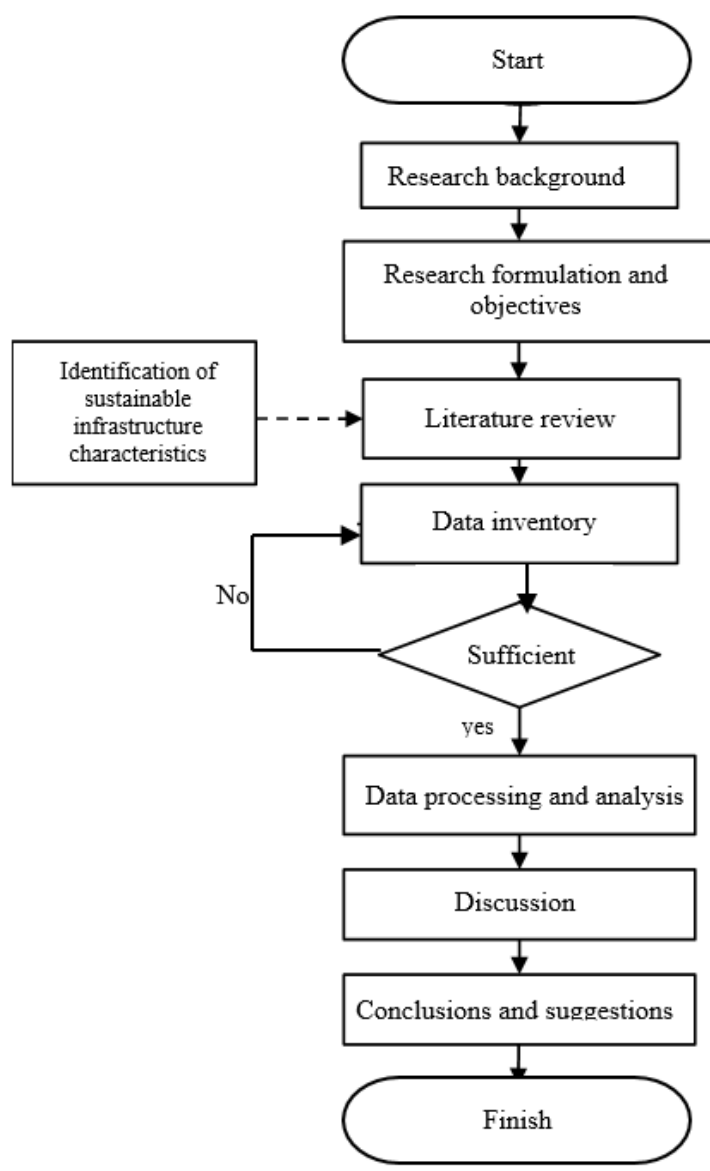

Figure 2. Research flow chart 


\section{RESULTS AND DISCUSSION}

\subsection{Reliability and Validity Test}

Validity test was carried out using the product moment correlation and the total number of respondents of 60 that resulted in the degree of freedom $\mathrm{N}-2=60-2=58$ and the value of $\mathrm{R}$ on the two-tailed test of 0.2542 with $5 \%$ significance (Sugiyono, 2015).

From the calculation results, the variable 'Find' conflicting policies and regulations (X3.8) was found being invalid and was not taken into account for further analysis. As for reliability, it was measured with the Cronbach's Alpha method and the Cronbach's Alpha value of 0.971 was obtained ( $>$ 0.60 ), therefore it could be concluded that the indicators have a high-reliability level (Sekaran \& Bougie, 2010).

\subsection{Normality Test}

The normality test showed abnormal results, which means that the questionnaire data distribution did not match the normal distribution. Interval type data with normal distribution would be more appropriate if using parametric data analysis. However, for this study, ordinal type data, with abnormal data distribution and limited sample data compared to the number of construction workers, it would be more appropriate if the data processing uses non-parametric method. Therefore, in the Non-Parametric Test analysis was used (Pramadini, 2016).

\subsection{Respondent Analysis Based on Certification}

In order to evaluate whether the certification ownership affected the answer given on the research variables, the Mann-Whitney test was conducted and the result shows that respondent's certification does affect the results of answer on variables shown in Table 3. This might be due to the fact that the characteristics of the Sustainable Infrastructure are already known and understood by the respondent through seminars, training, or competency test.

\subsection{Respondent Analysis Based on Work Type}

In order to evaluate whether work type differences affected the answer given on the research variables, Kruskal-Wallis test was conducted. From the distribution of data by type of work, respondents who have the role as project owner, consultant, and contractor are $36.67 \%, 30 \%$, and $33.33 \%$, respectively. The result shows that respondent's work type does affect the answer result on 6 variables, as shown in Table 4.
The results also show that the respondents from consultants have a higher level of interest compared to the answers of project owners and contractors. This may be due to the deeper understanding of sustainable infrastructure characteristics of the consultant than the project owner and contractor. In addition, there is a difference of interest or purpose among the respondents due to their position in the project, this then affects the decision-making process of respondents in the variable.

Table 3. Mann-Whitney result variable (respondent's certificate)

\begin{tabular}{ll}
\hline \multicolumn{2}{l}{ Indicator } \\
\hline $\mathrm{X}_{2.1}$ & Improving community's life quality \\
$\mathrm{X}_{2.3}$ & Developing local skill and ability \\
$\mathrm{X}_{2.4}$ & Increasing public health and security \\
$\mathrm{X}_{2.8}$ & Encourage alternative transportation mode \\
$\mathrm{X}_{3.9}$ & Increasing service time \\
$\mathrm{X}_{5.4}$ & Avoid geological destruction \\
$\mathrm{X}_{5.11}$ & Maintaining species biodiversity \\
$\mathrm{X}_{5.12}$ & Controlling destructive species \\
$\mathrm{X}_{6.3}$ & Measure climate threat \\
$\mathrm{X}_{6.5}$ & Prepare for long-term adaptability \\
\hline
\end{tabular}

Table 4. Kruskal-Wallis result variable (respondent's work type)

\begin{tabular}{ll}
\hline \multicolumn{2}{l}{ Indicator } \\
\hline $\mathrm{X}_{2.7}$ & Increasing communication access and mobility \\
$\mathrm{X}_{2.9}$ & Increasing access to field, road, and security \\
$\mathrm{X}_{2.10}$ & Preserving local culture and history \\
$\mathrm{X}_{2.11}$ & Guarding local/traditional views and characters \\
$\mathrm{X}_{3.4}$ & Assign engagement from another party \\
$\mathrm{X}_{5.9}$ & Reduce effect from fertilizers and pesticides \\
\hline
\end{tabular}

\subsection{Respondent Analysis Based on Education Level}

In order to evaluate whether the education level differences affected the answer given on the research variables, the Mann-Whitney test was conducted. From the distribution of data by education level, there are $75 \%$ respondents who are a graduate degree, and the rest of $25 \%$ is undergraduate degree. There are 5 variables in which the respondent's education level affected the given answer result. The variables are shown in Table 5.

Table 5. Mann-Whitney result variable (respondent's education level)

\begin{tabular}{ll}
\hline \multicolumn{2}{l}{ Indicator } \\
\hline $\mathrm{X}_{2.12}$ & Increasing public space \\
$\mathrm{X}_{4.13}$ & Supervise water cycle \\
$\mathrm{X}_{5.5}$ & Maintain the function of flood areas \\
$\mathrm{X}_{5.11}$ & Maintaining species biodiversity \\
$\mathrm{X}_{5.14}$ & Maintaining the function of wetlands and surface \\
& water \\
\hline
\end{tabular}


It can be concluded that the education level of the respondents influences the answer, where the higher the level of education, the differences in the importance of the variables become increasingly indicated. This may be the case because some of the sustainability characteristics of Infrastructure variables are learned or recognized by respondents as they continue their studies. In addition, by getting a higher level, the knowledge of the respondents will increase and the latest information will be obtained.

\subsection{Descriptive Analysis}

The qualitative descriptive of the impact of sustainable Infrastructure characteristics on project implementation in the field was assessed by calculating mean and median values through applying descriptive analysis. The results of the implementation of the Sustainable Infrastructure characteristics in the field are shown in Table 6. If the condition is distinguished between certified and non-certified skill workers, the result would be as seen in Figure 3.

Table 6. Descriptive Analysis Result

\begin{tabular}{lllll}
\hline $\begin{array}{l}\text { Percentage of } \\
\text { characteristic } \\
\text { implementation } \\
\text { on the field }\end{array}$ & $\begin{array}{l}\text { Frequ } \\
\text { ency }\end{array}$ & $\begin{array}{l}\text { Percent } \\
\text { age }\end{array}$ & $\begin{array}{l}\text { Valid } \\
\text { percent } \\
\text { age }\end{array}$ & $\begin{array}{l}\text { Cumula } \\
\text { tive } \\
\text { percent } \\
\text { age }\end{array}$ \\
\hline $21 \%-40 \%$ & 4.0 & 6.7 & 6.7 & 6.7 \\
$41 \%-60 \%$ & 16.0 & 26.7 & 26.7 & 33.3 \\
$61 \%-80 \%$ & 22.0 & 36.7 & 36.7 & 70.0 \\
$81 \%-100 \%$ & 18.0 & 30.0 & 30.0 & 100.0 \\
& 60.0 & 100.0 & 100.0 & \\
\hline
\end{tabular}

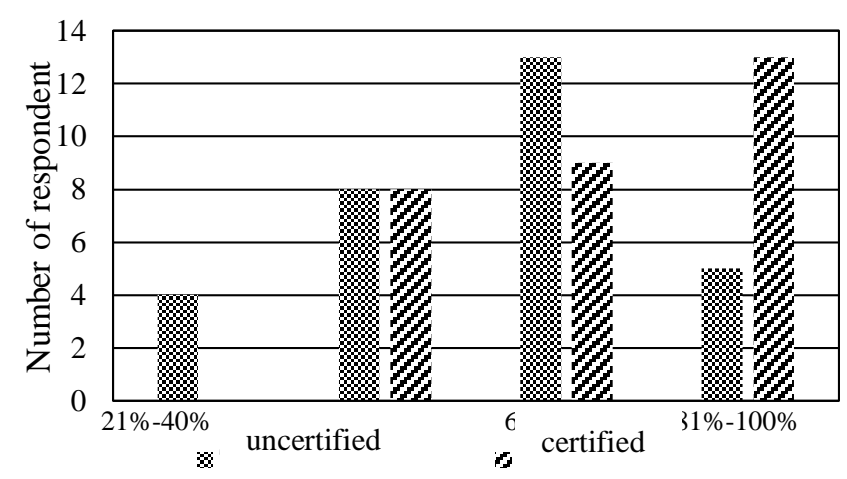

Figure 3. Respondents' project implementation

\subsection{Correlation Analysis}

The purpose of the correlation analysis is to verify whether there is a relation between knowledge variable of the Sustainable Infrastructure characteristic (X) and the project implementation (Y).

Based on Spearman correlation test result in which uses SPSS as auxiliary instrument, 57 variables have probability level of $<0.05$; z-score value obtained from the correlation value on the 57 variables $>\mathrm{z}$ table ( \pm 1.96$)$. Therefore it could be concluded that there is influence between the Sustainable Infrastructure characteristic knowledge with project implementation, on 57 out of 65 variables. Variables that were not correlated nor have no relation with the project implementation are shown in Table 7.

Table 7. Variables with no correlation

\begin{tabular}{ll}
\hline \multicolumn{2}{l}{ Indicator } \\
\hline $\mathrm{X}_{1.1}$ & Identification of interested parties \\
$\mathrm{X}_{1.2}$ & $\quad \begin{array}{l}\text { Choosing professional service provider according } \\
\text { to its appropriate field }\end{array}$ \\
$\mathrm{X}_{1.5}$ & $\quad$ Conducting integrated technical planning process \\
& $\quad$ with all involved parties \\
$\mathrm{X}_{1.6}$ & Reviewing the result on technical planning \\
$\mathrm{X}_{3.8}$ & Locate conflicting policies and regulations \\
$\mathrm{X}_{4.3}$ & Using recycled materials \\
$\mathrm{X}_{4.5}$ & Redirecting trash from landfills \\
$\mathrm{X}_{4.12}$ & Reduce drinking water/clean water consumption \\
\hline
\end{tabular}

6 smong 57 variables have correlation value of $>0.5$, which is a tight relation; whereas 51 variables have correlation value of $<0.5$ which means the relationship is not tight.

\subsection{Discussion}

From the obtained questionnaire, it was revealed that part of the construction skilled workers have heard and knew about the Sustainable Infrastructure.

After the questionnaires were distributed and the answers were revealed, then it could be further found about respondents' knowledge on each characteristic of the Sustainable Infrastructure. Based on the Likert scale, the respondents' answers were grouped into two answer levels, whereas respondents who chose N/A, 1 , and 2 were considered less understand; while ones who chose 3, 4, and 5 were considered have better understanding. Result of characteristic knowledge that was grouped based on Likert scale numbers is shown in Figure 4.

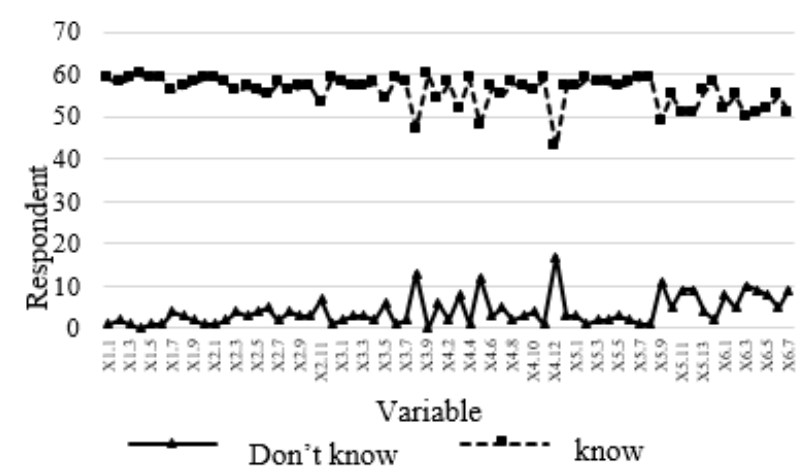

Figure 4. Sustainable Infrastructure characteristic knowledge 
Most of the construction skilled workers respondents showed that they already know the characteristic of the Sustainable Infrastructure. Some characteristics' term might be new, but it could be understood by construction community with further socialization and introduction; therefore the field implementation could also be improved.

From the analysis, it was revealed that certification alone does not affect construction skilled worker's knowledge on Sustainable Infrastructure characteristic. In the other hand, there are several variables affected by certification. This might be caused by knowledge difference between certified workers and non-certified workers.

If the respondents' answers were classified by grouping based on certification, then the difference of answers between certified and non-certified skilled workers could be seen in Figure 5. Figure 5 shows that there was not much difference of answers between both construction skilled workers. As for the project implementation, Figure 6 shows comparison of implementation percentage of certified skilled workers to non-certified skilled workers.

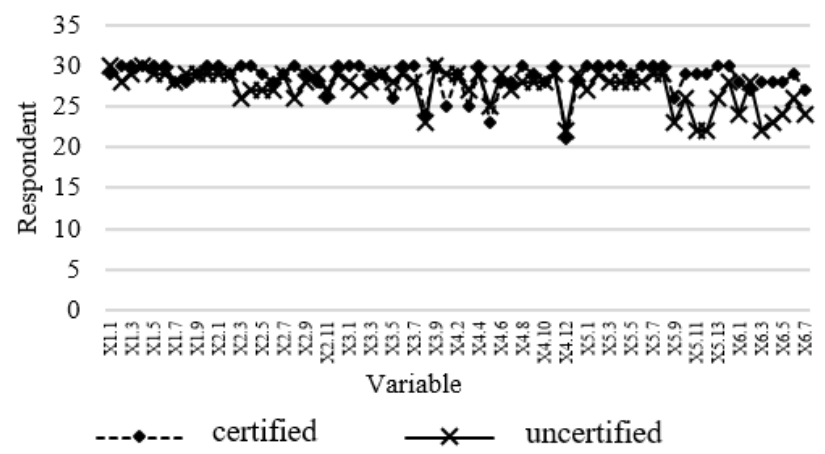

Figure 5. Sustainable Infrastructure characteristic knowledge (certified workers)

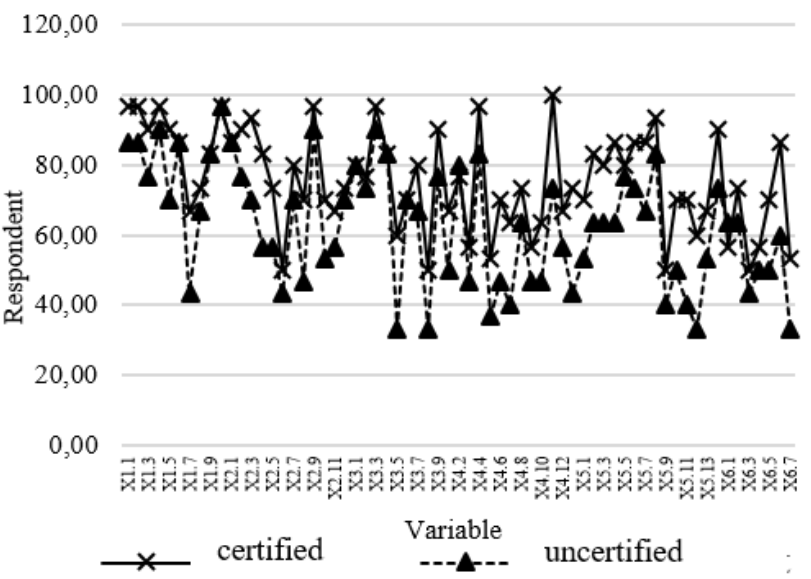

Figure 6. Respondent's project implementation percentage
There is significant difference in project implementation carried out by respondents. Certified workers show a higher work percentage than uncertified workers. It indicates that although there is little difference in the two types of workers in understanding the characteristics of Sustainable Infrastructure, there are significant differences in project implementation. This is might be due to the more certified skilled workers who understand and apply their knowledge in the projects the work.

The analysis was also carried out to identify the characteristics of Sustainable Infrastructure that has been known by construction workers. The results of the analysis show that the answer with option 5 on the Likert scale is the only answer taken, where the percentage of the answer is less than $50 \%$ of respondents. It was shown that the result of almost all of the characteristics that have option 5 as the answer was less than $50 \%$, which are 54 variables. This means that respondents have not considered that these characteristics as important, particularly the Climate and the Resource Allocation sub-groups. Most of the recent constructions are focused more on the implementation of the project itself, due to lack of infrastructure facilities. According to the respondents, most of the Sustainable Infrastructure characteristics have been implemented, while the others are less implemented in the project. This might attribute from the lack of understanding on the importance of the characteristic.

\section{CONCLUSIONS}

It results that $90 \%$ of certified skilled workers, or 27 out of 30 people, have heard the term Sustainable Infrastructure. Whereas, for non-certified skilled workers is only $63.3 \%$, or 19 out of 30 .

Certified skilled workers who understand the characteristic of Sustainable Infrastructure is within average of $95.4 \%$, whereas the number is only $91.1 \%$ for non-certified skilled workers. In the case of a characteristic implementation on the field, $75.9 \%$ have put it into practice for certified workers, whereas only $62.8 \%$ for non-certified skilled workers.

In terms of identification of the level of importance in the characteristics of Sustainable Infrastructure, there are 54 variables that have less than 50\% answer options on the Likert scale. This indicates that respondents have not considered this characteristic to be important, due to lack of understanding of the Sustainable Infrastructure. In the case of implementation of sustainable Infrastructure characteristics, there are 8 variables that are implemented less than $50 \%$ of respondents. This 
means that although respondents do not adequately understand the characteristics of Sustainable Infrastructure, most of its characteristics have been applied in the field.

\section{SUGGESTIONS}

In the future, it is expected that, especially for skilled workers as the spearhead of construction community construction, should continue to improve their capabilities and knowledge on infrastructure development, especially knowledge on sustainable infrastructure that can be applied later in project implementation. One of which is through training, seminar or workshop. Furthermore, awareness of the important effect of sustainable project development in the project construction community needs also be improved continuously. There was not much difference between both construction skilled workers groups' answers. As for the project implementation, Figure 6 shows comparison of implementation percentage of certified skilled workers to non-certified skilled workers.

There was a visible, significant, difference in the project implementation conducted by the respondents; certified workers showed higher percentage than the non-certified workers. This then pointed that although there is not much of difference in both workers types on knowing the Sustainable Infrastructure characteristics, yet it is different in the terms of project implementation. Whereas more certified skilled workers that understand and implement it in the project they undertake.

The respondents' answers then were used to identify characteristics of the Sustainable Infrastructure that has not been known by the construction skilled workers. For these characteristics, answers with choice 5 on the Likert scale were the only one taken; the percentage of the answer was less than $50 \%$ of the respondents.

It was shown that the result of almost all of the characteristics that have choice 5 as the answer was less than $50 \%$, which are 54 variables. This means that respondents have not considered these characteristics as important. Several of the Sustainable Infrastructure characteristics have not been deemed important to the construction skilled workers, particularly the Climate and the Resource Allocation sub-groups, which have a smaller percentage. Most of the recent constructions are focused more on the implementation of the project itself, due to lack of infrastructure facilities.
According to the respondents, most of the Sustainable Infrastructure characteristics have been implemented, while the others are less implemented in the project. This might attribute from the lack of understanding on the importance of the characteristic.

\section{REFERENCES}

Basso \& Louise, T., 2012. An Investigation into Sustainable Building Evaluation Strategies for use within the Canadian Forces and the Department of National Defence. Thesis ed. Kingston, Ontario, Canada: Queen's University.

Goeritno \& Bambang, 2011. Menuju Pembangunan Konstruksi yang Berkelanjutan [Towards Sustainable Construction]. Majalah Kiprah, 47(NovemberDesember 2011).

Kakkar \& Anju, 2014. Training Construction Workers for Sustainable Environment. International Journal of Environmental Research and Development, IV(1), pp. 21-26.

Ministry of Public Works and Housing, 2014a. Decree of Ministry of Public Works and Housing No. 24. Guideline for Construction Competency based Training, Jakarta: Ministry of Public Works and Housing.

Ministry of Public Works and Housing, 2014b. Decree of Ministry of Public Works and Housing No.

5. Guideline for Construction Competency based Training. Jakarta: Ministry of Public Works and Housing.

Ministry of Public Works and Housing, 2015. Decree of Ministry of Public Works and Housing No. 5. Guideline for Implementation of Sustainable Construction. Jakarta: Ministry of Public Works and Housing.

Pramadini, N., 2016. Pengaruh Sertifikasi Tenaga Kerja Ahli Pada Pembangunan Infrastruktur Berkelanjutan [Certification of Skilled Workers on Sustainable Infrastructures], Yogyakarta: Master Thesis. Faculty of Engineering. Universitas Gadjah Mada.

Rasekh \& Haleh, 2013. Delivering the Vision of Sustainable Buildings. Thesis ed. New South Wales: University of Wollongong, Australia.

Rodriguez, S., Roman, M., Sturhahn, S. \& Terry, E., 2002. Sustainability Assessment and Reporting for the University of Michigan's Ann Arbor Campus. Report ed. Michigan, America: University of Michigan. 
Sekaran, U. \& Bougie, R., 2010. Research Methods for Business: A Skill Building Approach. 5th ed. New York, America: Jhon Wiley \& Sons, Ltd.

Sugiyono, 2015. Statistik Nonparametrik untuk Penelitian. Bandung, Indonesia: CV Alfabeta.

Usman \& Furqan, 2010. Pengaruh Penerapan Green Construction pada Bangunan Gedung terhadap Kinerja Mutu Proyek di Lingkungan PT. X [Influence on the Implementation of Green Construction towards Project Quality Performance in PT.X]. Thesis ed. Jakarta, Indonesia: Universitas Indonesia.
World Commission on Environment and Development, 1987. Development and International Economic Co-Operation: Environment. Report ed. Oslo, Norway: World Commission on Environment and Development.

Yuan, M., 2011. An Integrated Knowledge Management Framework for Manging Sustainability Knowledge in the Australian Infrastructure Sector. Disertasi ed. Brisbane, Queensland, Australia: Queensland University of Technology. 
[this page intentionally left blank] 